\title{
Strategic Communications and Corporate Branding: A Study of Jebsen \& Jessen Indonesia Group
}

\author{
${ }^{1}$ Heny Wahyu Tamara Dwi Lestari, ${ }^{2}$ Dindin Dimyati, ${ }^{3}$ Mohammad Shihab \\ 1,2,3 School of Humanities, President University, Jababeka Education Park, Cikarang, Indonesia \\ E-mail: 'hwtamara@hotmail.com, ${ }^{2}$ dindin.dimyati@president.ac.id, ${ }^{3}$ shihab@president.ac.id
}

\begin{abstract}
Corporate communications hold a vital function to maintain the company's positive image and reputation in front of stakeholders. A corporate communications practitioner must be able to handle a variety of communication processes in an organization, including determining the right strategy to reach its communications goal. The purpose of this research is to analyse the corporate communications strategy of Jebsen \& Jessen Indonesia Group to creates its corporate branding and reflect it with public relations strategic planning process. The researchers gathered the primary data from in-depth interview with key informant and combine it with secondary data from other relevant data. Afterwards, triangulation is used to strengthen the credibility of data and continue with analysis process. This research has concluded that Jebsen \& Jessen Indonesia Group implements its corporate branding strategy according to public relations strategic planning process. Some of the targets have been achieved in one year period; however there have been suggestions to improve the future corporate branding strategy formation.
\end{abstract}

Keywords: corporate communications, corporate branding, public relations strategic planning process

\begin{abstract}
Abstrak. Komunikasi perusahaan memiliki fungsi yang sangat penting dalam menjaga citra positif dan reputasi perusahaan di hadapan para pemangku kepentingan. Seorang praktisi komunikasi perusahaan harus mampu melaksanakan sejumlah proses komunikasi dalam sebuah perusahaan, termasuk menentukan stretegi yang tepat untuk meraih sasaran komunikasinya. Tujuan penelitian ini adalah untuk menganalisa strateg komunikasi perusahaan Jebsen \& Jessen Indonesia Group dalam menciptakan 'branding' perusahaannya and mereflesikannya dengan proses perencanaan strategis public relations. Peneliti mengumpulkan data primer melalui wawancara mendalam dengan informan utama dan menggabungkannya dengan data sekunder dari data relevan lainnya. Data yang terkumpul kemudian diverifikasi melalui triangulasi untuk memperkuat kredibilitas data dan selanjutnya dilanjutkan dengan proses analisis. Penelitian ini menyimpulkan bahwa Jebsen \& Jessen Indonesia Group sudah melaksanakan strategi 'branding' perusahaannya sesuai dengan proses perencanaan strategis public relations. Beberapa targetnya sudah dicapai dalam waktu satu tahun, namun terdapat beberapa saran untuk memperbaiki pembentukan strategi 'branding' perusahaan di masa mendatang.
\end{abstract}

Kata kunci: komunikasi perusahaan; 'branding'perusahaan; proses perencanaan strategis public relations. 


\section{INTRODUCTION}

Current trend of business is forcing the business players itself to generate innovation and competitive power to stay in the business. In twentieth century era, every one agree that the value of corporation is not always about selling product and services but success (Podnar, 2015), as Steyn and Niemann (2010) also said that shareholder is not the vital stakeholder for business anymore. As well as to build the great success, a corporation need to establish a synchronized business environment by having a good way communication to such parties, for instances clients, stakeholders, employees, government, and unions where the corporate communications skills need.

The function of corporate communication in an organization was integrating several fields; such are corporate advertising, internal communication, media relations, investor relation and other. Indeed, corporate communication is also considered to have a managerial function that is responsible to supervise the activities of communication process toward internal and external as it has mentioned before (Cornelissen, 2011).

Steyn (2002) conceptualize three roles of a corporate communications practitioner based on the view of chief executive officer, for example: a) the role of strategist, which is referring to the top management role; b) the role of the manager, be regarded as role in the functional management and handle to elaborate more the corporate communications strategy; c) the role of the technician, applicable in low-level (micro) management of the organization. Goodman (2004) says that the corporate communications have a strategic importance to conserve the corporate internal image and culture through a set procedure to encounter the strategic goal, to reflect constant message and deliver it to its public including in crisis situations in one organization.

Jebsen \& Jessen Indonesia Group has established the business in Indonesia for more than 40 years, altogether by running various businesses such as manufacturing sector. Starting from 2015 , the company see the opportunity to open their path to gain more values in the industry by having a wider market by establish corporate communications department in Indonesia office with purpose to create its corporate branding. Prior to this, Jebsen \& Jessen (SEA) as the headquarter handled the corporate communications inquiries. However, the company seemed too late to take the move for corporate communications and corporate branding while at the same time some of similar companies have been implemented the strategy far before today.

Refer to the condition above, this research will focus on the presence of corporate communications in Jebsen \& Jessen Indonesia Group and analyze its strategy to create corporate branding. The objective is to reflect the corporate branding strategy of Jebsen \& Jessen Indonesia Group with the Nine Step of Strategic Public Relations by Ronald Smith (2005) with limitation of specific case study only.

This research us expected to give an important significance to related parties in the field of educational research and development, which are academic and practical significance. Since the research will discuss about the corporate communications and strategy, therefore it will be very useful for readers to understand the concept of this topic comprehensively. Hopefully, through this research, readers and future researchers are able to develop more strategy in order to prepare the new challenges ahead in corporate communications field. 
Heny Wahyu Tamara Dwi Lestari, dkk. Strategic Communications and Corporate...

Moreover, this research is also expected to be beneficial for those who work as a communication practitioner or those who interested in this particular topic.

\section{Corporate communications}

Corporate communications is a whole structure of coordination within the communication in an organization in order to build and manage good reputation toward the stakeholders, together as an incorporation of the messaged being delivered to public by a single unit (Cornelissen, 2008; Podnar, 2015). It includes the distribution of common information by appointed person in an organization to increases the ability to remain the operational authorization (van Riel \& Fombrun, 2007), furthermore it denotes as a set of communication activities to endorse the product and service in the organization itself (Johan \& Noor, 2013). Corporate communications is also defined as a whole event for internal and external communication management with the target to generates advantageous impression with related stakeholders. There are communication management, organizational communication, strategic communication, business communication and corporate communications including public relations and marketing communications (Elving, 2012; van Riel \& Fombrun, 2007; Gregory, 2007).

Corporate communications should be able to have good skills on management communication, business communication, and organizational communication. Moreover, Cutlip and colleagues argue that public relations have the objective to establish and maintain the beneficial relationship among the organization and stakeholders (as cited by Steyn, 2002).

UK Chartered Institute of Public Relations (CIPR) defines public relations as a field that is managing the reputation with structured planning in order to create and sustain positive feedback among the organization and its public (Gregory, 2010). In creating corporate branding, there are several communication strategies in order to approach the stakeholders.

Freemanhasdevelopedastakeholder theory and defines stakeholders as a people who receive certain impact, either advantages or disadvantages by the corporation itself (as cited by Ali et al, 2015; Rawlins, 2006; Gregory, 2007). It describes procedural and practical facets of communication together with the communication methods that can be used by manager inside and outside the organization.

Gregory (2007) explains stakeholders are the contributors on a relationships exchanges whereby it resulted the corporate brand as a contract between the company and stakeholders itself as the theory acknowledged the natural relationship between a group of individuals and organizations itself. Therefore, stakeholders involve on the development process of corporate branding. Furthermore, she develops a model of power/interest matrix as a tool to categorize the stakeholders in strategic planning. This model focus on the power of stakeholders to encourage other and the interest own by them toward a certain issue.

\section{Corporate identity, image, and reputation}

Every corporate communications activity is a representation of its effort to achieve the goal, which creates a good reflection of organization's identity, image, and reputation. An organization need to be recognized by its stakeholder as the valuable mark that differentiates them from others. Corporate communications need to serve variety of communication effort in order to convey the message as one entity (Podnar, 2015) and it should be a good picture for the organization. It is important to differentiate between the 
three terms as each of them has different approach to be accomplished. Identity, as a general is the characteristic that can be signified by its public. Image, is a picture that represented the organization in public's thought. Reputation is a whole perception of the organization as a result of a long-term image. Majority stated that image and reputation has an interconnection that make both terms similar in some ways.

Abratt writes (quoted by Oliver \& Allen, 2004) that corporate identity is a set of sign that can acknowledge the organization and make a differentiation towards others, which also embody the organization. Abratt and Kleyn (2012) elaborated that corporate identity is consisting upon two aspects, there are strategic formulation and how the corporate express it. Corporate expression refers to a company's decision related to visual identity, the brand promise, brand personality and brand communication. Therefore, it is also included as a part of corporate branding process. An organization as a company must realize that a consistent identity is important. Through a good management of corporate identity, it is able to obtain a positive image from internal and external public. Therefore, in the future it can deliver the organization to generate a good reputation in nature (Vella \& Melewar, 2008). Herstein et.al (2008) believe that a good corporate identity management process should cover internal and external stakeholder all at once, therefore the value of corporate identity communicated to organization's member and customer is equal and be in accordance in a long term.

Corporate image is the whole perception or face desired by a company to be perceived by its stakeholders (Van Riel \& Fombrun, 2007). As the research by Williams and Moffit recommend that corporate image is a dynamic paradigm affected by its recipient (stakeholders) and reflected through attitude and behaviour (as cited by Tan, Nguyen, Melewar, \& Bodoh, 2015). Van Riel and Fombrun (2007) describe reputation as the appraisal from stakeholders towards the company' performance to accomplish their expectations in common. Prior to it, Fombrun has argued that corporate reputation caused by the result of strategic communication of an organization and being shaped by the elaboration of a media or analysts (as cited in Van Riel $\&$ Fombrun, 2007). Therefore, corporate reputation is principally suitable to be an assessment of overall communications system being applied in a company. An organization basically does not have a solid reputation at once; the process is coming through whole interactions of stakeholders. The overtime interaction within several stakeholders with aspects that have brand-associated is able to strengthen one perception at once, known as brand image (Abratt \& Kleyn, 2012).

\section{Corporate branding}

At the moment there are many brands which have been raised in a business industry both locally and globally. The competition for a company to get the recognition from a consumer is increasingly tightened because of that. Alizadeh and colleagues (2014) define brand itself as a mixture of corporate principle, product's value, and implicit pledge from corporation for its customers, which include visible and invisible characteristics. According to (Keller \& Aaker, 2003), brand is able to generate a perception towards viewer through combine several attributes such as voice, picture, and expression reflected in the brand. It is in line with the definition from Kotler, brand is any combination of term, symbol, and picture intended to distinguish one product compare to another product (as cited by Đorđević, 2008). 
Heny Wahyu Tamara Dwi Lestari, dkk. Strategic Communications and Corporate...

It is important to have an outstanding corporate branding in the current business environment like today. Especially, for the company that has a positive business growth and wide expansion. The corporate branding was created through a process of several activities that involve internal and external stakeholders (van Riel \& Fombrun, 2007). It is not a oneperson job to create a successful corporate branding. Corporate brand encompasses two distinct characteristics: corporate expression, connect the identity and brand of a company; and stakeholder's perception toward particular brand (Abratt \& Kleyn, 2012).

\section{Strategic planning for public relations}

Wheelan and Hunger say that strategic planning is a set of multiple processes to reach goals, which serves a structure and executed by using specific tools and techniques (as cited by Sirisagul, 2015). Meanwhile, Smith (2005) argues strategic planning for public relations inseparable from decision-making process through cognitive understanding about communication field itself together with other disciplines. The benefit of having a planning is which it offers essentials way with observation from many perspectives and being thoughtful (Knights, 2001).

Strategic planning for public relations formed by Ronald Smith consists of four phases and elaborated into nine integrated steps that distributed within each phase. The model is called as the Nine Steps of Strategic Public Relations as follows:

Formative research is the preliminary action conducted with purpose to collects information and data, which will be used to analyze the condition before constructing the strategy. This phase contains of three steps where the planner need to do a careful analysis that will help the planner to determine future decision for the following phase.
Step 1: Analyzing the Situation.

Step 2: Analyzing the Organization.

Step 3: Analyzing the Publics.

Strategy is the core of strategic planning; the planner should take a real decision that has an effect to every action taken. This phase contains of three steps, such as following:

Step 4: Establishing Goals and Objectives. Step 5: Formulating Action and Response Strategies.

Step 6: Using Effective Communication.

This phase, tactics, consists of two steps that are regarding to communication tools will be used and the guide for implementation.

Step 7: Choosing Communication Tactics. Step 8: Implementing the Strategic Plan.

Additionally, there is specific difference between strategy and tactics. Both of terms refers to an effort in achieve a target. Strategy requires a wider set of identification to achieve the goal and it occur for long-term period. Meanwhile, Tactics used to apply specific effort to reach the goals and prefer as a responsive oriented (Austin \& Pinkleton, 2006).

Evaluative research. This final phase allows the planner to measure and evaluate all the work whuch has been done according to the goals and objectives. It will be useful for future improvement of another programs or activities.

Step 9: Evaluating the Strategic Plan.

At this final step, it usually determines a particular process or method to evaluating the strategy result.

\section{METHODS}

The researchers assume that a single study case is the most suitable approach being used because the interest was focusing on one bounded context of corporate communications strategy of Jebsen \& Jessen Indonesia Group in create its corporate branding, as Yin states that researchers chose a case study because of the purpose to explore a contextual 
condition which must be relevant with their interest of phenomenon (as cited by Creswell, 2007). In-depth interview and online interview were executed by continuity or in sequence, for instances the online interview was taken after the in-depth interview in order to explore more questions that need a further confirmation or when the researchers find new questions regarding to the research.

The researchers collected primary data from in-depth interview as the main instrument and secondary data from company profile, company website and company's document. After the information and data have been gathered, researchers will analyse the data by using coding and interpretation analysis. A single case study approach was used in this research to gain a deeper understanding about particular event or phenomenon (Daymon \& Holloway, 2011; Flick, 2009). In this research, the interview guide was classified based on four phases in the Nine Steps of Strategic Public Relations.

Eventually, by using triangulation process all the data resources collected are verifiable in order to strengthen the credibility of the data (Carter et.al. 2014). The key informant was sufficient for this research, as Daymon and Holloway (2011) explained that the key informant acknowledges detail information about the culture, history and communication process in a group. In semi-structured interview, interviewer usually prepares an interview guide with arrangement of questions order (Harrell \& Bradley, 2009).

In the beginning there were two informants, however in the last minutes one of them rejected to get interviewed. Face to face and on line interviews were conducted to get the data needed.

\section{FINDING AND DISCUSSION}

This section discussed about the corporate branding strategic planning of Jebsen \& Jessen Indonesia Group reflected with the concept of Nine Steps of Strategic Public Relations. Every phase was elaborated all the communication effort that has been planned by corporate communication department, together with the analysis from researchers.

\section{Formative Research}

In the analysis on formative research, there are three steps that are applicable to support the ideas before constructing a strategic plan for corporate communications. First step, it is important to understand the situation that is facing by the corporate communications department in the company. Long before the department was established, Jebsen \& Jessen Indonesia Group face a problem that for more than 40-year existence in Indonesia, people still did not recognize the company. Majority stakeholders were only noticing the product name without knowing its parents company or its distributor company, which is Jebsen \& Jessen Indonesia Group and subsidiaries. This condition caused by the old objective of the company that is focusing on salesoriented only without concern on the corporate branding. The research shows business company used to have an old perspective to pursue a financial goal, moreover many business leader does not particularly understand the important of reputation management or strategic communication may highly affect their business (Steyn, 2009).

Moving forward, the board member who consists of top management and shareholder was looking forward the potential condition towards Indonesian market. They have perspective that many potential markets have not yet covered by the company. That was when Jebsen \& Jessen Indonesia Group came in the middle of 2015, replaced the existing management system. On behalf of the 
Heny Wahyu Tamara Dwi Lestari, dkk. Strategic Communications and Corporate...

idea, the board member identified two background factors in developing new strategy for Indonesia office. First, the movement of market where the environment of competitive world in Indonesia is changing, such as the rise of digital era. As Siano et.al., (2014) writes because of the huge transformation of the technology, a company is basically able to work efficiently to maximize the market by empowering the use of internet and related facility. It is also supported by the statement of Argenti and Barnes; and O'Reilly (as cited by Vernuccio, 2014, $\mathrm{p}: 214)$ :

"The most innovative trend of corporate communications in the digital environment has clearly been driven by the rapid development on a global scale of 'Web 2.0' "“

The second background was because Indonesia have a bigger chance for potential market towards Jebsen \& Jessen Indonesia Group as the domestic condition shows a dynamic economic growth. The board member assumed that Indonesia happen to be a unique market, therefore the company need a specific strategy to develop it. One of them was to establish the first independent corporate communications department in the whole group for Indonesia office in order to generate more awareness towards the stakeholders. In the other hand, the company was creating its corporate branding to have more engagement with the stakeholders. According to Steyn (2009), globally recent mindset of an organization is increasing to focus on the engagement towards stakeholder and particular group with social issue. The research has shown as cited by Gregory (2007), Cornelissen and Keller claims that by means of corporate communications is to managing an integrated communication among two sides; company and its stakeholders, in order to promote a positive perspective until it produces a value-added of the brand.

The situation analysis above has in line with the two situational approaches that happened to be opportunity and obstacle (Smith, 2005), it also can be done using SWOT analysis (Austin \& Pinkleton, 2006). The two background factors in developing new strategy represent the 'opportunity' as it provides a potential benefit toward the company, however the fact that previous situation of less recognition from the stakeholders represent the 'obstacle' that being faced by Jebsen \& Jessen Indonesia Group as it became the limitation for the company in implementing new branding strategy.

The second step refers to analysis of the organization and involves three aspects of the organization: internal

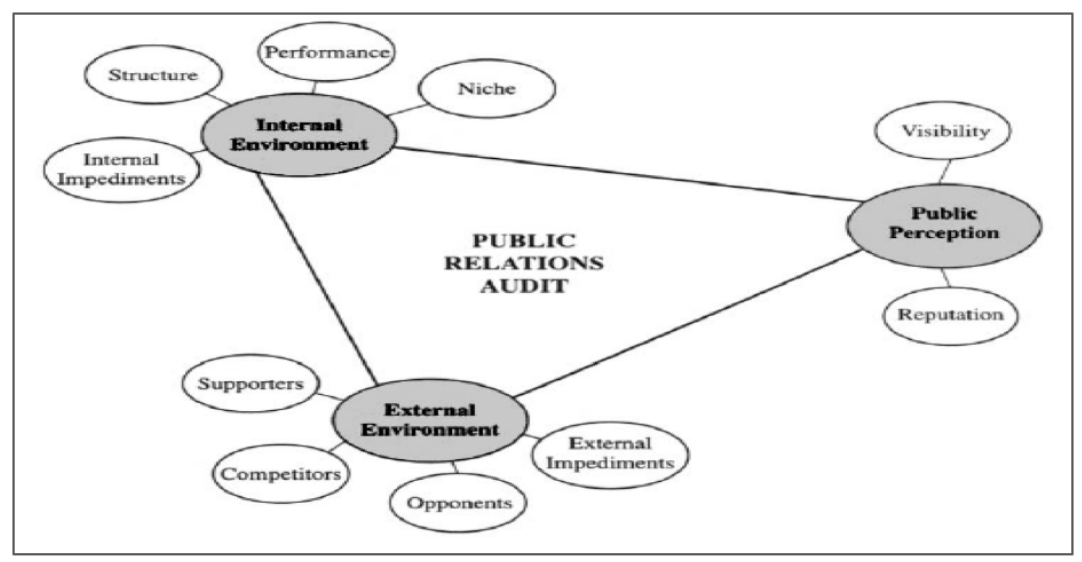

FIGURE 1: Public Relations Audit by Ronald Smith (2005) 
environment, external environment, and public perception (Smith, 2005).

\section{Internal environment}

The performance of Jebsen \& Jessen Indonesia Group was quite great, as it has a matured and stable viability in supporting the Indonesia industry for more than 40 years. Until now, the company has expanded its subsidiaries into five companies with 10 services center, 2 factories, and 30 offices all around the country (Corporate Communications Jebsen \& Jessen, 2016). The company specialty located in its management structure along with the five subsidiaries all at once, which involves in five industries with many varieties of products and services.

The corporate communications department was under the supervision of Chairman office, consisted of one Corporate communications Executives in-charge and supported by one employee member. The role of corporate communications in the company was advisory towards the top management, where the flow of work and decisionmaking came from bottom management to top management. For any resources related to the situation to be addressed was adaptable according to the need and inquiries on every project.

The fact that corporate communications was a new function in Jebsen \& Jessen Indonesia Group, therefore there always a trial and error in order to setting the right and effective strategy for the company, especially the corporate branding strategy. The adaptation also occurred towards the stakeholders, which are employees, customers, and managements.

\section{Public perception}

The visibility of Jebsen \& Jessen Indonesia Group in the face of public and stakeholders still remain low, meanwhile the reputation be regarded as one of the long-established industrial company in Indonesia. The company perceived its image as supportive; exist in the field, trustworthy, professionals, and prudence.

\section{External environment}

The industrial business environment in Indonesia is tightly competitive. Jebsen \& Jessen Indonesia Group basically does not have a truly-matched competitor; however there were several competitors in term of products, especially on heavy equipment, pumps, pharmacy and chemicals, cable, and refinery. Many of the competitors owned a national-wide reputation and dominated the market. The situation to create brand new image and reputation towards the stakeholders among the existed reputable companies become the main challenge for Jebsen \& Jessen Indonesia Group.

Finally, the last step in this phase was analyzing the public. The corporate communications of Jebsen \& Jessen Indonesia Group have identified their key stakeholders who have been targeted for its branding strategy. The corporate communication classified their stakeholders into two categories, internal stakeholders and external stakeholders. The internal stakeholders are all employees of Jebsen and Jessen Southeast Asia, the management inside Jebsen \& Jessen Indonesia Group; start from top management and all employees. The corporate communications aimed the internal stakeholders to enhance the communications within by involving them in the planning process and keep to informed them. Furthermore, the department would like to clarify the understanding of top-management regarding to the benefit of corporate communications.

Meanwhile, for external stakeholders there are three main targets: customer, academicians, and media. 
Heny Wahyu Tamara Dwi Lestari, dkk. Strategic Communications and Corporate...

Customer, the corporate communications claimed that its work should also be impacted to the business by create communication program which can help the sales-department easier to approach the customer and potential customer. Approach to academicians was aimed to engage with top university and graduates in order to recruited high quality resources as the effort to improve employer branding.

This goal is in line with the statement: .."the core within corporate branding was to keep a preservation towards the current employees together with interesting potential candidates to be recruited, but Hatch and Schultz stated somehow the potential employees used to be neglected in corporate branding literature (as cited by Foster, Punjaisri, \& Cheng, 2010)".

Meanwhile, media were targeted as key stakeholder in line with the purpose of its corporate branding to create awareness. The media already own its target audiences indeed, which were including the customers, potential customers, and association that related and beneficial for Jebsen \& Jessen Indonesia Group business. As an additional, the corporate communications department does not handle investor relations as they stated that the company is a family enterprise who does not own a specific investor, unless the shareholders in top management of regional office.

\section{Strategy}

\section{Goals and objectives}

In order to create an effective strategy, the purpose of its plan must be concrete and clear. Identified the goals and objectives was able to ease the corporate communications in defining what action should be needed in their strategy. The goals of corporate communications of Jebsen \& Jessen Indonesia Group in 2016 period creating corporate branding in order to reinforce the corporate's image in front of targeted stakeholders who are customers, academicians, and media. Furthermore, the company also aims to increase stakeholder's awareness towards the company and to maintain favourable relationship with its stakeholders.

Smith (2005) elaborates that "Positioning" was also important for a company before set-up the goals and objectives. Positioning refers to a process in creating such a distinguished characteristic intended by the organization and to be perceived by its stakeholders. Some organization have proven this idea enable them to make them steady in chasing a dynamic change of situation. According to Ind, in order to exceed all of the variety stakeholders, the goals and objectives must be identified explicit positioning (as cited by Oliver S., 2010). The positioning intended was Jebsen \& Jessen Indonesia Group wants to be known as a company that have been supported the industry in Indonesia for a long time. Finally, the corporate communications department categorized its objectives based on each stakeholder.

The objectives of internal stakeholder were to enhance employees sense of belonging towards Jebsen \& Jessen Indonesia Group and to promote corporate brand through its employee; towards customer was to promote Jebsen \& Jessen Indonesia Group extensive business range to existing customers and potential customers; towards academician was to extend the presence in labor market and attract high qualify future employee to join Jebsen \& Jessen Indonesia Group; towards media was to create an extensive presence and awareness to selected public through selected offline and online media; and towards public was to create an awareness of Jebsen \& Jesssen Indonesia Group of companies to all level of publics.

In order to prioritize the objectives 
of strategy, the corporate communications department was generated the tangible action weight. For brand identity, reputation, and organizational culture was worth to $30 \%$, meanwhile for the relationship management towards the stakeholder worth to $25 \%$. Furthermore, adjusting organizational strategies worth to $25 \%$, and facilitated business process was $20 \%$. Even though the corporate communications have prepared it, the more specific measurable objectives were able to serve a better precise standard. Moreover, it will also help to define the evaluation to each objective.

In preparing the strategy for corporate branding, the corporate communications department was reflecting to their functional process in the company as an advisory function (Victor, 2017). The strategy-making process was adapting bottom to top decision-making flow. It starts with the corporate communications department initiates the strategy and propose it to top management members to be decides. The result of analysis after in-depth interview shows several strategies that have been accomplished by corporate communications for period of 2016 and mostly categorized on proactive strategies.

\section{Proactive strategies}

Smith (2005) categorized some proactive strategies in formulating the strategic public relations. Based on the review of information gathered, the corporate communication of Jebsen \& Jessen Indonesia Group has included some of them as an agenda. The following were the proactive strategies: 1) organizational performance; developing new media platform such as website and social media, 2) audience participation; conducting a sales networking event which targeted for sales marketing employees in all subsidiaries, 3) special events; involved in the Indonesia Economic Forum event and held career seminar in some university, 4) alliances and coalitions; cooperated with university in Indonesia in academic and career development and joined as a member of Indonesia Economic Forum, 5) publicity; approach some media editor interpersonally to build media relations, news release, and engaged with influencer, 6) sponsorship; prepares to contributed as a sponsorship specifically on university.

The other strategy was to identify the message sources in the company, it refers to the corporate communications decision to choose the company spokesperson. Based on the data gathered, the company's spokesperson is not only one person. The corporate communications accommodate all the subsidiary companies to have their own spokesperson. This term applied in order to adjust the needs of particular requirement, such as media conference. If the communication needs required whole group inquiries, therefore the Chairman of Jebsen \& Jessen Indonesia Group will take in-charges as the spokesperson. However, if the communication need required a technical or specification of the product, therefore a related-president director or manager is the one who incharges as the spokesperson. The reason was based on the expertise and the inquiries, the corporate communications need to identify by themselves who will be fit to be the spokesperson.

Jebsen and Jessen Southeast Asia (SEA) as the regional-based company has determine the use of any term that related to corporate identity, such as logo, symbols, and more. Corporate communications department authorized to set the corporate identity guidelines and this regulation applicable to all companies in ASEAN. In order to make its corporate identity recognizable, Jebsen and Jessen Southeast Asia (SEA) input the Corporate Identity Guideline in the official company website: http://www.jjsea.com/doc/ 
CorporateIdentityGuidelines. Jebsen and Jessen present an appeal from its logo as the representation of favorable characteristics of quality, trust and longevity (Jebsen \& Jessen (SEA), 2011). As it has been mentioned before, the corporate brand involved as the corporate expression and its identity, it includes any effort to communicate corporate identity to all stakeholders (Abratt \& Kleyn, 2012).

The corporate communications department encouraged internal branding by created corporate attributes which also an effort to strengthen its corporate identity, it was also an effort to strengthen corporate identity to internal stakeholders. The attributes were tie, scarf, pin, and cufflinks, with the characteristics of corporate logo and color. The idea was to suggest all employees to use the attributes in special occasion together and able to be use at daily work schedule. It was accordingly with Herstein et.al (2008) that a good corporate identity management process should cover internal and external stakeholder all at once, therefore the value of corporate identity communicated to organization's member and customer is equal and be in accordance in a long term.

\section{Tactics}

Choosing an effective communication tactics should be accordance with the needs of the branding strategy, because it basically has a wide scope and may possibly change over time (Smith, 2005). At this stage, there are categorization in choosing a media to deliver the communication tactics of the company.

\section{Media control ability}

Based on the media control ability, Jebsen \& Jessen Indonesia Group owned both controlled and uncontrolled media. For the controlled, there are: brochure, newsletter, company profile video, website, and social media. Besides, there are the uncontrolled media which has started since the first-time corporate communications department established.

\section{Internal and external media}

The second category classified the media into internal media and external media. Internal media is usually attached with the controlled media and circulated for internal group only. Newsletter published through the office intranet called 'MORUS' where it enables all employees to access and composed the latest news from each company all over ASEAN in accordance with company's term and condition. Company profile video is usually being played for some occasion such as new employee induction. Meanwhile, the website and social media were fully controlled by corporate communications department including the content management. For external media, the company was open to any publicity with proper media monitoring towards each news coverage. Recently, the company deals with newspaper, magazine, and online media including blog.

\section{Breadth of media}

Based on the size and breadth of the media, the corporate communications have determined its targeted media upon printed and online media, which later also belong to media categorization based on technical production with topic specification of industrial media. However, Television and Radio was not included as tools for the communication tactic by considering the audience scope of both media were too sporadic and the cost was more expensive.

\section{Organizational media}

Furthermore, when choosing communication media tactics, it was included the strategy to selecting organizational media. Jebsen \& 
Jessen Indonesia Group owned three organizational media as mentioned in previous categorization and were classified based on the target audiences. For the customers, brochures and corporate presentations are still used to accommodate the promotional material of products and services. If it regards to academicians and potential customers as target audiences, therefore they prefer to use digital media such as website and social media. Digital media may cover a broader target that possibly able to rise more effectiveness and efficiency. According to Vernuccio (2014), social media was dynamically shifting and it allows the users to have control of the content management, distribution, and its application in each steps of brand communicating process.

The official website of Jebsen \& Jessen Indonesia Group may serve as the main channel of company's information that also leads to corporate branding effort to create awareness from its stakeholders. There are three social media being prepare, such as LinkedIn, Facebook, and Instagram. According to the data, those three-social media recorded on five most popular social media platforms in 2016 with percentages: Facebook (68\%), Instagram (28\%), and LinkedIn (25\%) (Pew Research Center, 2017). Both websites and social media were still in the stage of launching preparation on February, 2017.

In order to get effective feedback from operating the social media for organization, the research has shown that good content management was important. Kilgour et.al. (2015) identified the social media transformation from content into strategy, they categorized it based on: (1) the social media context; material should not be commercial and underwrites the public's interest to inspires them spreading the messages, (2) the user's motivation; shared a self-motivation to readers by posted information that serves a personality message, and (3) the corporation; starts to build a good relationship with influencers that related to company's context.

One more is news media tactics, the corporate communications still doing a conventional way through News Release in every event and face-to-face approach to some media editor in order to build good media relations.

\section{Budgeting and timeline}

On the next steps, it will discuss the implementation of strategy that are summarize into budgeting and strategic timeline of corporate communications department in Jebsen \& Jessen Indonesia Group. Regarding to the budgeting, the corporate communications department should prepare one year period budget in the beginning year. The budget must be aligned with the planning, then it should be reported to top management to gain approval.

The corporate communications were creating its strategic timeline starting from each project planning on behalf of several considerations. The first consideration was because every planning needs a preparation both preevent and post-event. Second is that every strategy of corporate communications must align with all subsidiaries. Since the subsidiary companies in Jebsen \& Jessen Indonesia Group have a marketing department, it means there is a possibility for some of their program may take effect toward the strategic timeline of corporate communications. Therefore, it was an obligation for them to informed corporate communications regarding to their own timeline and vice versa. The coordination like this could prevent a schedule crash between marketing and corporate communications department, especially when both department is collaborating some event. 


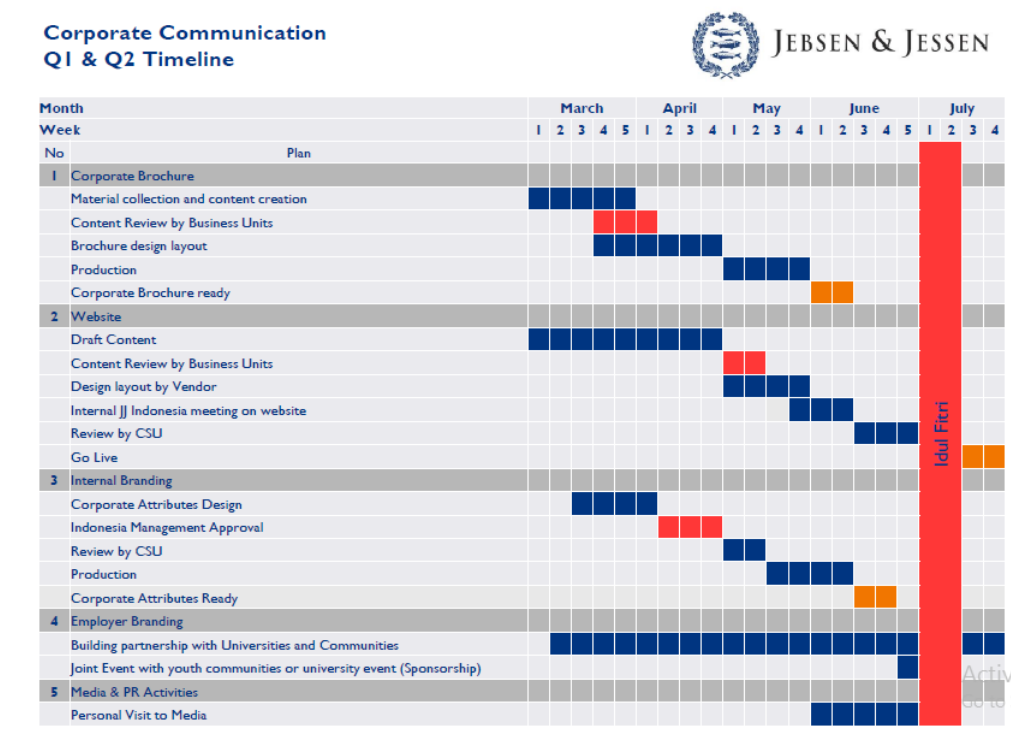

FIGURE 2: Gantt chart example of corporate communications Jebsen \& Jessen Indonesia Group

The corporate communication department organized its timeline using Gantt Chart model. Gantt Chart is a flow chart table model developed by Henry Gantt, this model combine a multiple task in a program with specific time or period towards each task (figure 2).

By using this model, the corporate communication can estimate to achieve all the activities at once, furthermore this model provide the users to distributes all activities with convenient spare time, whereby they can prepare earlier from the target schedule of implementation.

\section{Evaluative research}

Corporate communications department does not have a specific measurement for the achievement of its branding strategy that has been accomplished. Regarding to the media publicity, the corporate communications is measuring the value of money. For the customers, it will return back to its subsidiaries which the program department is work or not. In the end of the program, there is an annual evaluation. Meanwhile, for the project such as social media and website, it will be evaluated every six months. The evaluation report will be provided and reported to the board member in the end of project to be review. This evaluation report will become the basis for future strategy and implementation activities.

In a total, the summary achievement of corporate communications department was gained more than twenty publicities in a year; held a career seminar in Brawijaya University, Gadjah Mada University, and Binus University; involved in the event of Indonesia Economic Forum as a speaker and reach ten potentials business opportunity in the same time, some of them were exceeded the achievement. However, it will be better if the corporate communications department determined the measurement method for more promising evaluative assessment.

Recent evaluative activities were assessed by only analyzing the direct feedback from program that has been done. For instances, after three or five-year the corporate communications held a public survey regarding to corporate branding of Jebsen \& Jessen Indonesia Group in order to measure the effectiveness of strategy and its achievement. Austin and Pinkleton (2006) conceptualized a guideline to evaluating public relations' work, it 


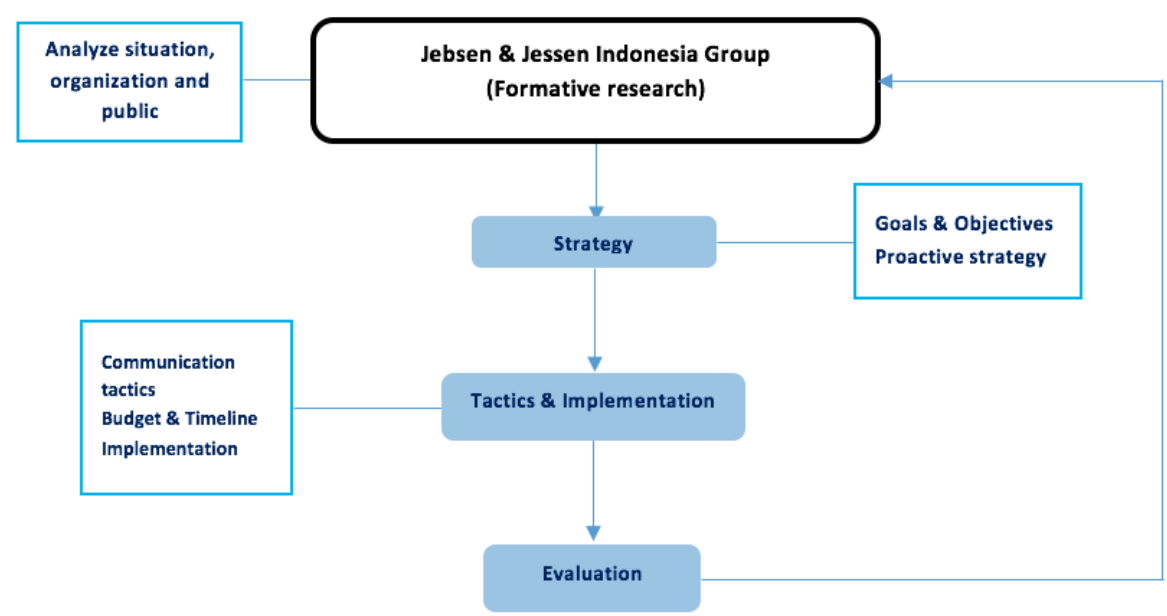

FIGURE 3. Jebsen \& Jessen Indonesia Group strategic communications framework

was consisted of four activities: Media content analysis, Cyberspace analysis, Trade show and event measurement, and public opinion polls.

For the future research, we recommend to do a research in specific strategy or tactic, for example the utilization of social media towards the corporate branding strategy. Furthermore, future researchers could also research to evaluate the whole program in certain period of years.

\section{CONCLUSION}

Based on the research that has been implemented, the researchers conclude that the development of strategy adopted by corporate communications department of Jebsen \& Jessen Indonesia Group has corresponded with the Nine Steps of Strategic Public Relations. The strategy has worked in some way, proven with the fact that some goals have been achieved, specifically on media publicity which exceeded the target. However, there were suggestions that could be improved in order to achieve more targets in corporate branding, such as determined specific measurable objectives and added evaluative measurement tools.

\section{REFERENCES}

Abratt, R., \& Kleyn, N. (2012). Corporate identity, corporate branding and corporate reputations: Reconciliation and integration. European Journal of Marketing, 1048-1063.

Ali, I., Jiménez-Zarco, A.I. and Bicho, M. (2015). "Using Social Media For CSR Communication and Engaging Stakeholders", in Adi, A., Grigore, G. and Crowther, D.(eds), Corporate Social Responsibility in the Digital Age. Bingley: Emerald Group Publishing Limited, pp. 165-186.

Alizadeh, A., moshabaki, A., Hoseini, S. H., \& Naiej, A. K. (2014). The Comparison of Product and Corporate Branding Strategy: a conceptual framework. IOSR Journal of Business and Management, 14-24.

Austin, E. W., \& Pinkleton, B. E. (2006). Strategic Public Relations Management: Planning and Managing Effective Communication Programs. New Jersey: Lawrence Erlbaum Associates, Inc.

Carter, N., Bryant-Lukosius, D., DiCenso, A., Blythe, J., \& Neville, A. J. (2014). The use of triangulation in qualitative research. Oncology Nursing Forum, 41(5), 545-547. doi: 10.1188/14. onf.545-547 
Heny Wahyu Tamara Dwi Lestari, dkk. Strategic Communications and Corporate...

Cornelissen, J. (2011). Corporate Communication: A Guide to Theory and Practice. London: SAGE.

Corporate Communications Jebsen \& Jessen. (2016). Jebsen \& Jessen Indonesia. Retrieved from Jebsen and Jessen (SEA): $\quad h t t p: / / w w w . j j s e a . c o m / d o c /$ AboutUs

Creswell, J. W. (2007). Qualitative Inquiry \& Research Design: Choosing Among Five Approaches. California: Sage Publications, Inc.

Daymon, C., \& Holloway, I. (2011). Qualitative Research Methods in Public Relations and Marketing Communications. New York: Routledge.

Đorđević, B. (2008). Corporate strategic branding: How country and corporate brands come together. Ekonomski Anali, 53, 59-88. http://doi. org/10.2298/EKA08177059D

Elving, W. J. (2012). Corporate Communication Positioned within Communication Studies - Corporate Communications, an International Journal: The Journal and its History, Scope and Future Developments. Review of Communication, 66-77.

Flick, U. (2009). An Introduction to Qualitative Research. London: SAGE Publication, Ltd.

Foster, C., Punjaisri, K., \& Cheng, R. (2010). Exploring the relationship between corporate, internal and employer branding. Journal of Brand \& Management, 401-409.

Goodman, M. B. (2004). Today's corporate communication function in S. M. Oliver, Handbook of Corporate Communication (pp. 217-224). New York: Routledge.

Gregory, A. (2007). Involving Stakeholders in Developing Corporate Brands. Journal of Marketing Management Volume 23, 2007 - Issue 1-2.

Gregory, A. (2010). Planning and Managing Public Relations Campaigns: A Strategic Approach. London: Kogan Page.

Harrell, M. C., \& Bradley, M. A. (2009). Data Collection Methods: Semi-Structured Interviews and Focus Groups. Santa
Monica: RAND Corporation.

Herstein, R., Mitki, Y., \& Jaffe, E. D. (2008). Communicating a new corporate image during privatization: the case of $\mathrm{El} \mathrm{Al}$ airlines. Corporate Communications: An International Journal, 380-393.

Jebsen \& Jessen (SEA). (2011). Corporate Identity Guidelines. Retrieved from Jebsen \& Jessen (SEA): http://www. jjsea.com/doc/VisualIdentity

Johan, M. R., \& Noor, N. A. (2013). The Role of Corporate Communication in Building Organization's Corporate Reputation: An Exploratory Analysis. Interdisciplinary Journal of Contemporary Research in Business, 1230-1240.

Keller, K. L., \& Aaker, D. A. (1990). The impact of Corporate Marketing on A Company's Brand Extensions in J. M. Balmer, \& S. A. Greyser (2003) Revealing the Corporation: Perspectives on Identity, Image, Reputation, Corporate Branding, and Corporate-level marketing (p. 272). New York: Routledge.

Kilgour, M., Sasser, S. L., \& Larke, R. (2015). The social media transformation process: curating content into strategy. Corporate Communications: An International Journal, 326-343.

Knights, K. (2001). Strategic Planning in Public Relations: A Practical Guide. London: Thorogood.

Melewar, T. C., \& McCann, C. D. (2004). Facets of the global corporate in S. M. Oliver, Handbook of Corporate Communications and $P R$ (pp. 175182). New York: Routledge.

Oliver, S. (2010). Public Relations Strategy. London: Kogan Page.

Oliver, S. M., \&Allen,A.C.(2004). Reputation and leadership in a public broadcast company in S. M. Oliver, Handbook of Corporate Communication (p. 254). New York: Routledge.

Pew Research Center. (2017, January 11). Which social media platforms are most popular. Retrieved from Pew Research Center: http://www.pewinternet.org/ chart/which-social-media-platformsare-most-popularl

Podnar, K. (2015). Corporate 
Communications: A Marketing Viewpoint. New York: Routledge.

Rawlins, B. L. (2006). Prioritizing Stakeholders for Public Relations. http://www.instituteforpr.org/ prioritizing-stakeholders/

Riel, C. B., \& Fombrun, C. J. (2007). Essentials of Corporate Communication: Implementing Practices for Effective Reputation Management. New York: Routledge.

Siano, A., Piciocchi, P., Bassano, C., Palazzo, M., Siglioccol, M., \& Luca, D. D. (2014). Ingredient Branding Strategy in Manufacturing Sector: Enhancing the Value Proposition. XXVI Convegno annuale di Sinergie, 269-278.

Sirisagul, K. (2015). Roles of Practitioners and Strategic Planning Practices. http://www.prthailand.com/images/ articles/Practitioners.pdf.

Smith, R. D. (2005). Strategic Planning for Public Relations. New Jersey: Lawrence Erlbaum Associates, Inc.

Steyn, B. (2002). From A Stretegy To Corporate Communication Strategy: A Conceptualisation. Paper delivered at the 19th International Public Relations Research Sysmposium, Lake Bled, Slovenia.

Steyn, B. (2009). The Strategic Role of Public Relations Is Strategic Reflection: A South African Research Stream.
American Behavioral Scientist, 516532.

Steyn, B., \& Niemann, L. (2010). Enterprise strategy: A concept that explicates corporate communication's strategic contribution at the macroorganisational level. Journal of Communication Management, 106126.

Tan, M. A., Nguyen, B., Melewar, T. C., \& Bodoh, J. (2015). Exploring the corporate image formation process. Qualitative Market Research: An International Journal, 87-115.

Vella, K. J., \& Melewar, T. C. (2008). Explicating the relationship between identity and culture: A multiperspective conceptual model in T. $C$. Melewar, Facets of Corporate Identity, Communication, and Corporate Reputation (p. 11). New York: Routledge.

Vernuccio, M. (2014). Communicating Corporate Brands Through Social Media: An Exploratory Study. International Journal of Business Marketing, 211-233.

Victor, P. (2017, January 10). Corporate Communications Strategy to build Corporate Branding of Jebsen and Jessen Indonesia Group. A Report. (H. $\mathrm{W}$. Lestari, Interviewer) 